\title{
Impact of Chronic Constipation on Lower Urinary Tract Symptoms and Uroflowmetry Parameters in Men
}

\author{
Erkeklerde Kronik Konstipasyonun Alt Üriner Sistem Semptomları ve Üroflowmetri \\ Parametreleri Üzerine Etkisi
}

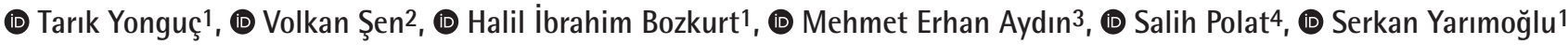 \\ 1 University Health Science, Izmir Bozyaka Training and Research Hospital, Clinic of Urology, Izmir, Turkiye \\ 2 Manisa State Hospital, Clinic Urology, Manisa, Turkiye \\ ${ }^{3}$ Dr. Yaşar Eryılmaz Doğubayazıt State Hospital, Clinic of Urology, Ağrı, Turkiye \\ ${ }^{4}$ Amasya University Sabuncuoğlu Şerefeddin Training And Research Hospital, Clinic of Urology, Amasya, Turkiye
}

\section{What's known on the subject? and What does the study add?}

In the management of lower urinary tract symptoms (LUTS), it is important to recognize the dynamics of the bladder, prostate and urethra, bladder neck and that symptoms may result from interactions of these organs as well as with the central nervous system. Although constipation and LUTS are very common in elderly men, most of the studies about the relationship between LUTS and constipation were carried out in children or young female population. The main purpose of this study is to determine the patients with constipation who will least benefit from benign prostatic obstruction (BPO) treatment in daily urologic practice and to protect them from BPO treatment complications.

\begin{abstract}
Objective: To evaluate the benefits of functional constipation (FC) management in male patients with male lower urinary tract symptoms (LUTS) coexisting with FC.

Materials and Methods: We conducted a prospective study including 1748 men over the age of 40 who were admitted to our clinic with newly diagnosed male LUTS. The patients were evaluated by history, International Prostate Symptom Score (IPSS), uroflowmetry, urinalysis, serum prostate-specific antigen testing, measurement of prostate volume by ultrasonography and post-void residual urine volume. Rectal fleet enema was administered in patients with FC diagnosed according to the Rome III criteria. Uroflowmetry tests were repeated 12 hours after enema. The patients were re-evaluated after treatment with oral sennoside once a day for a month.

Results: At the end of the $1^{\text {st }}$ month, 62 patients with male LUTS and FC were re-evaluated. The difference between maximum flow rate 0 max values before the treatment of constipation and in the $1^{\text {st }}$ month after the treatment was statistically significant $(p<0.001)$. There was a significant difference between the IPSS values before and at the $1^{\text {st }}$ month after the treatment $(p<0.001)$. The difference between the voided volumes in the 1st month following constipation treatment and those before the treatment and on the $1^{\text {st }}$ day after treatment was statistically significant $(p=0.003$ and $p=0.006$, respectively). The difference between quality of life scores of the patients before and at the first month after treatment was statistically significant $(p<0.001)$.

Conclusion: Treatment of FC in patients with LUTS coexisting with FC may decrease IPSS scores, increase uroflowmetry parameters and patient's quality of life. Thus, LUTS patients with FC will be protected from unnecessary medical and surgical treatments.
\end{abstract}

Keywords: LUTS, Differential diagnosis, Constipation, IPSS, ROME III criteria

Öz

Amaç: Alt üriner sistem semptomları (AÜSS) ve eşzamanlı fonksiyonel kabızlığı (FK) olan erkeklerde fonksiyonel kabızlığı tedavi etmenin faydalarını değerlendirmektir.

Gereç ve Yöntem: Yeni tanı alan AÜSS ile kliniğimize başvuran 40 yaş üzeri 1748 erkek hasta prospektif olarak çalışmaya dahil edildi. Hastalar; özgeçmiş, IPSS, üroflovmetri, idrar analizi, serum prostat spesifik antijen tayini, üriner sistem ultrasonografisi yardımı ile prostat hacmi ve işeme

Correspondence: Tarık Yonguç MD, University Health Science, İzmir Bozyaka Training and Research Hospital, Clinic of Urology, İzmir, Turkiye E-mail: tyonguc@gmail.com ORCID-ID: orcid.org/0000-0002-2131-0812

Received: 11.02.2019 Accepted: 28.02.2019

Cite this article as: Yonguç T, Şen V, Bozkurt Hi, Aydın ME, Polat S, Yarımoğlu S. Impact of Chronic Constipation on Lower Urinary Tract Symptoms and Uroflowmetry Parameters in Men. J Urol Surg 2019;6(4):308-313.

๑Copyright 2019 by the Association of Urological Surgery / Journal of Urological Surgery published by Galenos Publishing House. 
sonrası artık idrar volümü ölçümü ile değerlendirildi. Roma III kriterlerine göre tanı konan FK hastalarına rektal lavman uygulandı. Hastalar bir ay boyunca günde bir kez oral sennoside ile tedaviden sonra tekrar değerlendirildi.

Bulgular: Birinci ayın sonunda erkek alt üriner sistem şikayetleri ve FK olan 62 hasta yeniden değerlendirildi. Kabızlık tedavisinden önceki ve tedaviden sonra 1. aydaki Omax değerleri arasındaki fark istatistiksel olarak anlamlıydı $(p<0,001)$. Tedavi öncesi ve tedavi sonrası birinci aydaki IPSS değerleri arasında anlamlı fark vardı $(p<0,001)$. Kabızlık tedavisini takiben 1. aydaki idrar hacimleri ile tedavi öncesi idrar hacmi $(p=0,003)$ ve 1 . gün idrar hacimleri $(p=0,006)$ arasında anlamlı farklılıklar mevcut idi. Hastaların tedavi öncesi ve tedavi sonrası birinci aydaki yaşam kalitesi puanları arasındaki istatistiksel olarak anlamlı fark mevcuttu $(p<0,001)$.

Sonuç: Eş zamanlı AÜSS ve fonksiyonel kabızlığı olan hastalarda; fonksiyonel kabızlığın tedavisi total IPSS değerlerinde azalmaya, üroflovmetre parametrelerinde ve hasta yaşam kalitesi değerlerinde artmaya neden olabilir buna bağlı olarak da hastalar gereksiz cerrahi ve medikal tedavilerden korunabilir.

Anahtar Kelimeler: AÜSS, Ayırıcı tanı, Kabızlık, IPSS, ROME III kriterleri

\section{Introduction}

An international consensus conference defined lower urinary tract symptoms (LUTS) to include symptoms relating to storage and/or voiding abnormalities common in aging men (1). The most common etiological factor for LUTS in men is benign prostatic obstruction (BPO) (1). Overactive bladder/detrusor overactivity, primary bladder neck obstruction, urethral stricture, bladder neck contracture and detrusor sphincter dyssynergia may also cause LUTS. Increasing age, neurological conditions, recurrent urinary tract infection, irritable bowel syndrome, body mass index, exercise level, smoking and constipation are the risk factors of male LUTS (2). The urinary and gastrointestinal systems are in close anatomical relationship; moreover, the rectum and the urinary bladder have a common embryological origin. The parasympathetic innervations of each arise from pelvic parasympathetic outflow (S2-S4). Several reports showed that dysfunction of one system may affect the other $(3,4,5,6,7)$. Functional constipation (FC) is defined as a bowel disease causing persistently difficult, infrequent, or incomplete defecation, and not meeting criteria for Irritable Bowel syndrome (8).

Most of the studies about the relationship between LUTS and constipation were carried out in children or young female population. Although constipation and LUTS are very common in elderly men, to the best of our knowledge, there is only one prospective cohort study about the relationship between male LUTS and constipation (9). We aimed to evaluate the benefits of constipation management in male patients with LUTS coexisting with $\mathrm{FC}$, and its effect on decision of surgical treatment for BPO.

\section{Materials and Methods}

The study was approved by the hospital ethics committee (protocol number 02/12/2014, no.: 3) and all patients provided written informed consent. Among 1748 patients who were admitted to our clinic with newly diagnosed male LUTS between December 2014 and December 2015, 71 constipated patients over the age of 40 were included in the study. Inclusion criteria were: a maximum urinary flow rate ( 0 max) measured by uroflowmetry $<15 \mathrm{~mL} / \mathrm{s}$ (measured 2 times) and diagnosis of FC according to the Rome III criteria. Patients having cystitis, urinary stone disease, neurogenic diseases, prostate cancer, and previous surgery for BPO or taking any medication for LUTS were excluded from the study. The patients were evaluated by history, uroflowmetry, urinalysis, serum prostate-specific antigen testing, measurement of prostate volume by urinary system ultrasound (USG) and post-void residual urine volume (PVR). Patients with a PVR of $>100 \mathrm{~mL}$ were also excluded from the study. In addition, the Rome III criteria and International Prostate Symptom Score (IPSS) were used in all patients. The Rome III criteria are frequently used for the diagnosis of FC (10). Rectal fleet enema was prescribed for patients with FC diagnosed based on the Rome III criteria. The patients were told to use it a night before coming to the hospital and use a second one if the first enema did not resolve constipation. Uroflowmetry tests were repeated 12 hours after enema. Then, patients were treated with oral sennoside once a day for a month. The daily dose of sennoside was increased until FC was resolved and skipped if diarrhea was seen. After this treatment, the patients were re-evaluated by USG, uroflowmetry and IPSS questionnaire and the results were compared with initial results. Urinary symptoms-related quality of life ( $\mathrm{OoL})$ was assessed by the IPSS question 8 "If you were to spend the rest of your life with your urinary condition just the way it is now, how would you feel about that?".

In our study, to put forth the odds of overtreatment in patients with LUTS and FC; we asked the patients who agreed to participate in the study: "If a surgical treatment is offered for your LUTS, would you accept it?" (Figure 1).

\section{Statistical Analysis}

Statistical analyses were performed with the statistical package for the social sciences version 21 (SPSS, Chicago, IL). Continuous variables were presented as means and standard deviations and compared with the paired samples t-test. A $p$ value of $<0.05$ was set for statistical significance. 


\section{Results}

Of the 71 patients with FC, 65 agreed to participate in the study. At the end of the 1st month, 3 patients did not attend the follow-up visit, thus excluded from the study and 62 patients were re-evaluated (Figure 1). Table 1 summarizes the baseline characteristics of the patients. Omax, PVR, IPSS, voided volume, and $\mathrm{OoL}$ results of the patients before and after the treatment of constipation. There were no side effects in patients using oral sennoside. There was a significant difference between $0 \max$ values measured before constipation treatment and on the $1^{\text {st }}$ day after enema $(p<0.001)$ (Figure 2). The difference between Omax values before the treatment of constipation and in the 1st month after treatment was also statistically significant $(p<0.001)$. There was a significant difference between the IPSS values before treatment and in the $1^{\text {st }}$ month after treatment $(p<0.001)$ (Figure 3). There was no significant difference between the 0 max values on the first day and first month after treatment $(p=0.557)$. There was no significant difference between the voided volumes before the treatment and at the first day after enema $(p=0.081)$. The differences between the voided volumes at the 1st month following constipation treatment and those before treatment $(p=0.003)$ and on the $1^{\text {st }}$ day after treatment $(p=0.006)$. The difference between OoL scores of the patients before and on the first month after treatment was statistically significant $(p<0.001)$ (Table 2). Approximately 10\% of the 65 patients, who were included in the study, answered the question about surgical treatment "yes" (Figure 1). After the laxative treatment, none of the patients answered the same question "yes".

\section{Discussion}

In the management of LUTS, it is important to recognize the complex dynamics of the bladder, prostate, urethra, and the bladder neck and the fact that symptoms may result from interactions between these organs and their interactions with the central nervous system. Abnormalities within one system will affect the other because of the close anatomical proximity of the bladder and urethra to the rectum. Relaxation of the pelvic floor muscles and striated sphincters is necessary for normal micturition and defecation (11).

\begin{tabular}{|l|l|}
\hline \multicolumn{2}{|l|}{ Table 1. Patients' characteristics and demographic data } \\
\hline $\mathbf{n}$ & $\mathbf{6 2}$ \\
\hline Age (years) & $61.77 \pm 7.27(43-76)$ \\
\hline PSA (ng/mL) & $2.06 \pm 1.60(0.28-7.08)$ \\
\hline Prostate volume $(\mathrm{mL})$ & $48.84 \pm 9.72(30-75)$ \\
\hline Rome III criteria score & $4.9 \pm 1.04(4-7)$ \\
\hline Post voiding residual volume (PVR) (mL) & $24.35 \pm 19.30(0-50)$ \\
\hline
\end{tabular}

PSA: Prostate-specific antigen, PVR: Post-void residual, $n$ : Number of patients values were summarized as mean \pm SD (range)

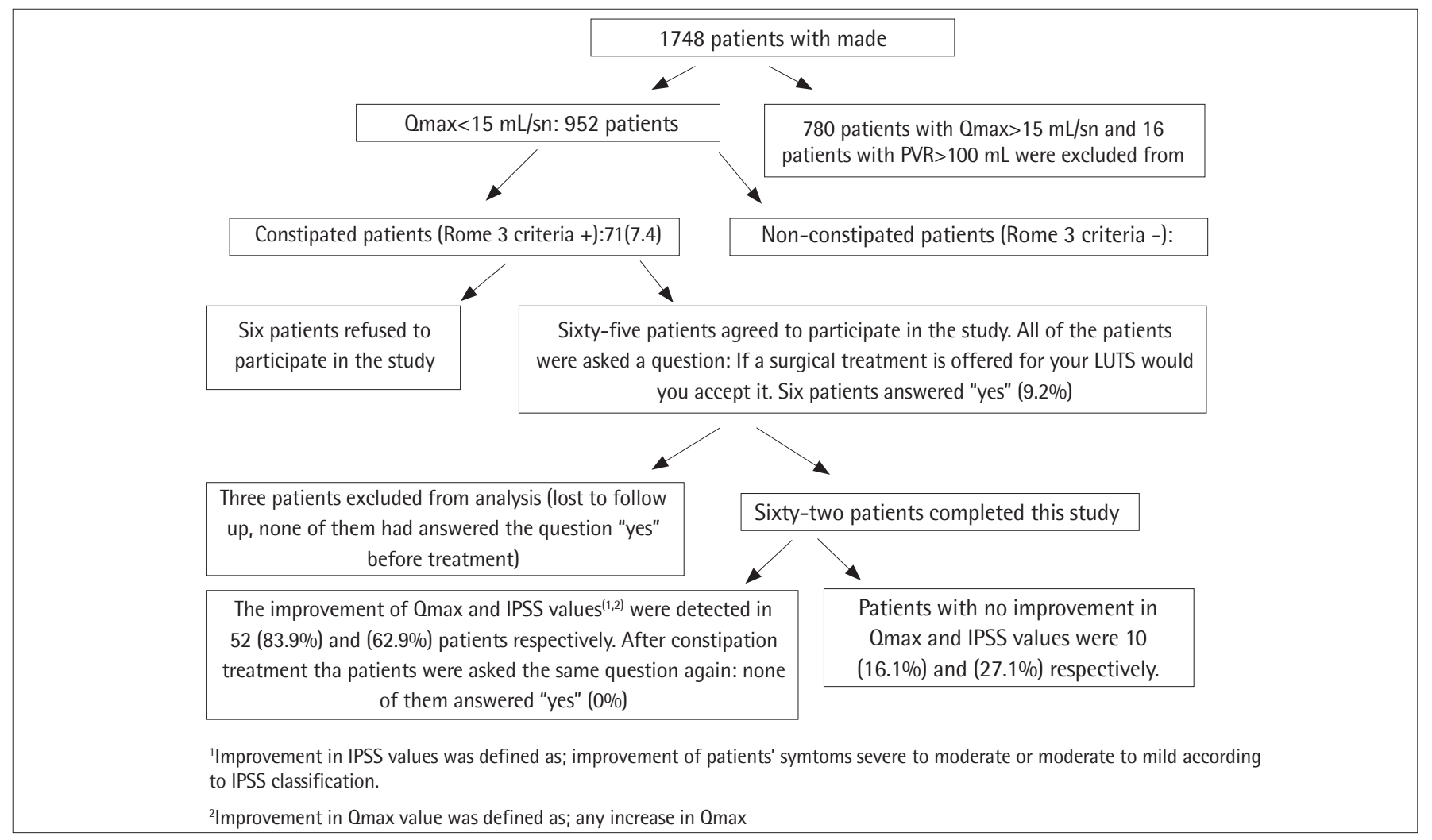

Figure 1. Flow chart of materials and methods 


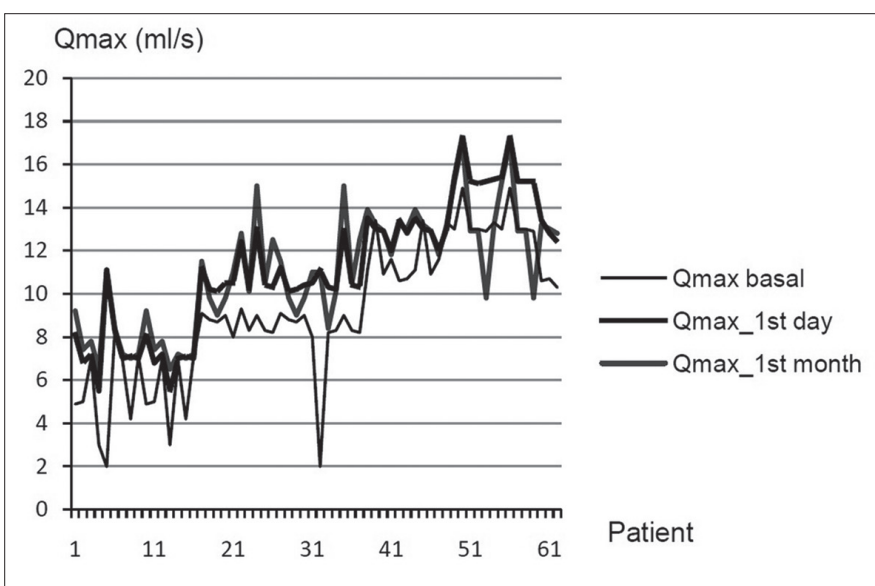

Figure 2. $Q \max (\mathrm{mL} / \mathrm{s})$ and International Prostate Symptom Score values of all patients at basal

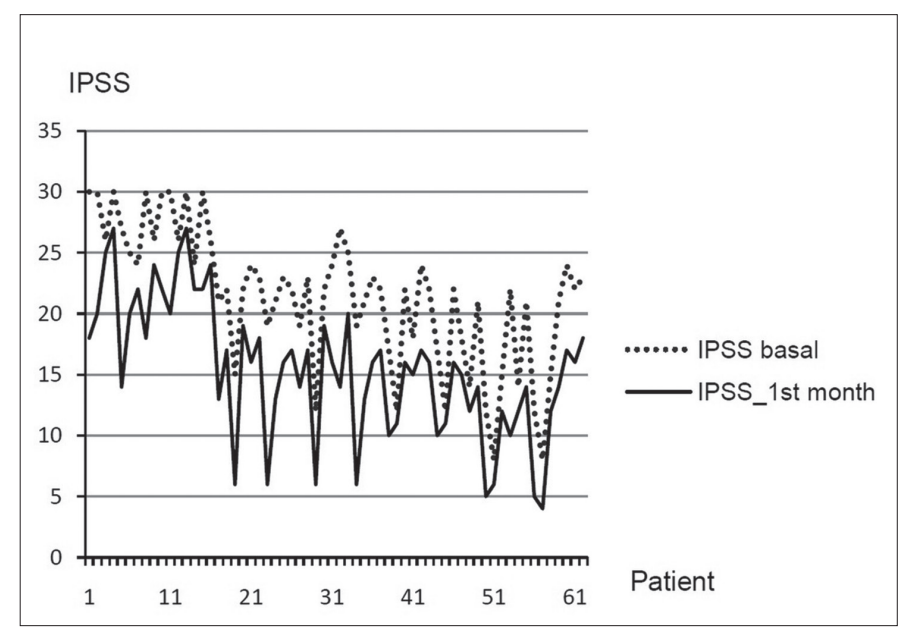

Figure 3. $1^{\text {st }}$ day and $1^{\text {st }}$ month following laxative treatment

\begin{tabular}{|c|c|c|c|c|}
\hline & $\begin{array}{l}\text { Before } \\
\text { treatment }\end{array}$ & $1^{\text {st }}$ day & $1^{\text {st }}$ month & p \\
\hline $\mathrm{Q}_{\text {max }}, \mathrm{mL} / \mathrm{s}$ & $\begin{array}{l}9.17 \pm 3.23 \\
(2.00-14.90)\end{array}$ & $\begin{array}{l}10.93 \pm 2.90 \\
(5.50-17.30)\end{array}$ & $\begin{array}{l}11.05 \pm 2.72 \\
(6.5-17)\end{array}$ & $<0.001^{¥}$ \\
\hline IPSS & $\begin{array}{l}21.26 \pm 5.72 \\
(7-30)\end{array}$ & - & $\begin{array}{l}15.58 \pm 5.15 \\
(5-27)\end{array}$ & $<0.001$ \\
\hline QoL ${ }^{\mu}$ & $4.68 \pm 1.28$ & - & $2.79 \pm 1.34$ & $<0.001$ \\
\hline $\begin{array}{l}\text { Voided } \\
\text { volume, } \mathrm{mL}\end{array}$ & $\begin{array}{l}223.7 \pm 101.5 \\
(84-582)\end{array}$ & $\begin{array}{l}251.4 \pm 90.4 \\
(143-599)\end{array}$ & $\begin{array}{l}270.1 \pm 72.2 \\
(153-496)\end{array}$ & $0.557^{\Uparrow}$ \\
\hline PVR & $\begin{array}{l}24.35 \pm 19.30 \\
(0-50)\end{array}$ & - & $\begin{array}{l}22.90 \pm 17.22 \\
(0-50)\end{array}$ & 0.659 \\
\hline \multicolumn{5}{|c|}{ 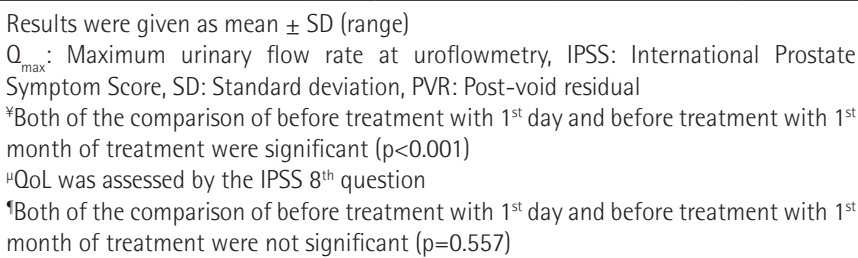 } \\
\hline
\end{tabular}

Koskimäki et al. (12) investigated the impact of non-urological diseases on LUTS in the general population. In this study, a LUTS questionnaire was mailed to a representative sample of 3143 Finnish men. They found that the relative risk of LUTS was increased more than expected among men suffering from arthritis, facal incontinence, constipation and neurological disease. They found that the prevalence of constipation among all age groups (age $>50$ ) was 7\% (11). In this study, we found that the prevalence of FC was 7.5\% in male patients with LUTS over the age of 40 years and it is not a small population that can be ignored. A strong association of constipation with LUTS indicated that problems in bowel or anal canal function may probably aggravate LUTS (13).

BPO is the most common etiological factor for male LUTS. Surgery is the current gold standard procedure for men with bothersome moderate to severe LUTS secondary to BPO. Although perioperative mortality and morbidity have decreased over time, we cannot ignore the considerable high morbidity rates ( $0.1 \%$ and $13.3 \%$, respectively) (14). Long-term complications are serious and comprise urinary incontinence, urinary retention, bladder neck contracture, urethral stricture, retrograde ejaculation, and erectile dysfunction $(14,15)$. All these complications cannot be underestimated especially in patients who will not benefit from surgical treatment. In addition, medicines used to relieve LUTS are not purely innocent. They have also many side effects such as hypotension, impotence and anejaculation. What is more, pharmacotherapy and surgery in BPO are associated with significant costs (16). Although the medical and surgical treatments are used widely, life style changes and the elimination of risk factors are mostly ignored by urologists. In the literature, the association between BPO and metabolic syndrome was confirmed in many studies and most of them showed improvement in LUTS with the treatment of metabolic syndrome (17). The other frequent treatable risk factor for FC in patients with LUTS is gastrointestinal disorders, especially constipation (13). The coincidence of LUTS and defecation problems has been reported in the literature with the possible different etiologies (18). The rectum and bladder are affected by the same neuropathology; dysfunction in one system may impede the neighboring organs and structures mechanically such as stool impaction from severe constipation may impede voiding or severe straining due to constipation may induce changes in the pelvic floor musculature (18). Approximately $30 \%$ of children with long-lasting FC present with abdominal and/or rectal fecal impaction, with overflow incontinence in $90 \%$ (19). While assessing patients with LUTS, only focusing on BPO may lead to overlooking the reason. In our study, severe constipation was the main reason for voiding dysfunction in a group of patients who presented to the urology clinic with LUTS and most of them were improved by the treatment of FC. Although, the IPSS scores were high 
before the sennaside treatment, we did not start alpha blocker treatment as we wanted to see the real effect of FC treatment on patients' LUTS. After the sennaside treatment the IPSS scores were significantly improved $(p<0.001)$. Prompt improvement in Qmax values and IPSS scores after constipation treatment suggests that the main reason for the LUTS in these patients was stool impaction which leads to direct pressure on the bladder neck and posterior urethra $(18,20)$. Also the improved results were stable with maintenance treatment with oral laxative at the 1st month visit. There are several complementary theories for the coexistence of bladder and bowel disorders (11). There is a hypothesis promulgates that prolonged external anal sphincter contraction in the presence of a large amount of stool leads to inappropriate pelvic floor muscle contractility and consequently concomitant urethral sphincter non-relaxation (11). After laxative treatment, pelvic floor muscle contractility and concomitant urethral sphincter relaxation may return to normal physiology. Most published studies that correlated rectal and bladder dysfunction were carried out in children or young women $(3,4,5,6,7)$. Urinary retention secondary to chronic constipation is a well-documented phenomenon, and it has been shown that treatment of constipation alone may improve both urinary retention and urinary incontinence in children (6).

To the best of our knowledge, only one prospective randomized study was reported in elderly men (9). Charach et al. (9) described chronic constipation as hard stool with fewer than 3 defecations per week and they demonstrated that medical relief of constipation significantly improved LUTS in elderly patients with decreasing of urgency, frequency symptoms and postvoiding residual volumes.

In our study, we asked 65 patients who agreed to participate in the study "If a surgical treatment is offered for your LUTS, would you accept it?" Among 65 patients, approximately 10\% answered the question "yes" (Figure 1). After one-month laxative treatment, none of them answered the same question "yes". Our study is the first study that demonstrates the increase in 0 max values after the management of $\mathrm{FC}$ and shows the importance of diagnosing $\mathrm{FC}$ before any treatment of $\mathrm{BPO}$, as there is always an overtreatment potential in male LUTS.

The main purpose of this study was to identify patients with constipation who will least benefit from BPO treatment in daily urologic practice and to protect them from BPO treatment complications. We used the Rome III criteria for describing chronic FC and we found that relieving constipation in patients with LUTS significantly improved Omax values, IPSS scores and QoL of patients. Thus, unnecessary surgical interventions and associated complications were avoided in this group of patients who will not benefit from classical BPO treatments. This study shows that urologists, before suggesting any treatment for patients with LUTS, should keep in mind coexisting FC which may be the main underlying condition and deserves priority treatment.

\section{Conclusion}

Although BPO is the most common cause of male LUTS, before deciding on a definitive treatment, urologists should take into consideration the functional connection between the bladder and bowel. Treatment of chronic constipation in male patients with LUTS coexisting with FC may decrease IPSS total scores, increase uroflowmetry parameters and patient's QoL thus; these patients will probably be protected from unnecessary medical and surgical treatments.

Presented In: This manuscript was presented as a poster at the $2^{\text {nd }}$ EAU Baltic Meeting in Riga, Latvia on 29-30 May 2015.

\section{Ethics}

Ethics Committee Approval: The study was approved by the hospital ethics committee (protocol number: (protocol number 02/12/2014, no.: 3).

Informed Consent: All patients provided written informed consent.

Peer-review: Externally peer-reviewed.

\section{Authorship Contributions}

Concept: T.Y., M.E.A., Design: T.Y., Data Collection and/or Processing: S.P., M.E.A., Analysis and/or Interpretation: V.Ş., H.I.B., S.Y., Literature Research: T.Y., V.S., Writing: T.Y., S.Y.

Conflict of Interest: No conflict of interest was declared by the authors.

Financial Disclosure: The authors declared that this study received no financial support.

\section{References}

1. Speakman $M$, Kirby $R$, Doyle $S$, Ioannou C. Burden of male lower urinary tract symptoms (LUTS) suggestive of benign prostatic hyperplasia (BPH) focus on the UK. BJU Int 2015;115:508-519.

2. C Coyne KS, Kaplan SA, Chapple CR, Sexton CC, Kopp ZS, Bush EN, Aiyer LP; EpiLUTS Team. Risk factors and comorbid conditions associated with lower urinary tract symptoms: EpiLUTS. BJU Int 2009;103:24-32.

3. McGrath $\mathrm{KH}$, Caldwell PH, Jones MP. The frequency of constipation in children with nocturnal enuresis: a comparison with parental reporting. J Paediatr Child Health 2008;44:19-27.

4. Carter D, Beer-Gabel M. Lower urinary tract symptoms in chronically constipated women. Int Urogynecol J 2012;23:1785-1789.

5. Chrzan R, Klijn AJ, Vijverberg MA, Sikkel F, de Jong TP. Colonic washout enemas for persistent constipation in children with recurrent urinary tract infections based on dysfunctional voiding. Urology 2008;71:607-610. 
6. Loening-Baucke V. Urinary incontinence and urinary tract infection and their resolution with treatment of chronic constipation of childhood. Pediatrics 1997;100:228-232.

7. Soligo M, Salvatore S, Emmanuel AV, De Ponti E, Zoccatelli M, Cortese M, Milani R. Patterns of constipation in urogynecology: clinical importance and pathophysiologic insights. Am J Obstet Gynecol 2006;195:50-55.

8. Longstreth GF, Thompson WG, Chey WD, Houghton LA, Mearin F, Spiller RC. Functional bowel disorders. Gastroenterology 2006;130:1480-1491.

9. Charach G, Greenstein A, Rabinovich P, Groskopf I, Weintraub M. Alleviating constipation in the elderly improves lower urinary tract symptoms. Gerontology 2001;47:72-76.

10. Mearin $F$, Lacy BE. Diagnostic criteria in IBS: useful or not? Neurogastroenterol Motil 2012;24:791-801.

11. Burgers RE, Mugie SM, Chase J, Cooper CS, von Gontard A, Rittig CS, Homsy $Y$, Bauer SB, Benninga MA. Management of functional constipation in children with lower urinary tract symptoms: report from the Standardization Committee of the International Children's Continence Society. J Urol 2013;190:29-36.

12. Koskimäki J, Hakama $M$, Huhtala $H$, Tammela TL. Association of nonurological diseases with lower urinary tract symptoms. Scand J Urol Nephrol 2001;35:377-381.

13. Kaplan SA, Dmochowski R, Cash BD, Kopp ZS, Berriman SJ, Khullar V. Systematic review of the relationship between bladder and bowel function: implications for patient management. Int J Clin Pract 2013;67:205-216.
14. Zantl N, Hartung R. TUR-Related Complications. In: Hohenfellner M, Santucci RA editors. Emergencies in Urology. Berlin: Springer, 2007:335348.

15. Rieken M, Ebinger Mundorff N, Bonkat G, Wyler S, Bachmann A. Complications of laser prostatectomy: a review of recent data. World J Urol 2010;28:53-62.

16. Nickel JC. BPH: costs and treatment outcomes. Am J Manag Care 2006;12:141-148.

17. Gacci M, Corona G, Vignozzi L, Salvi M, Serni S, De Nunzio C, Tubaro A, Oelke $M$, Carini $M$, Maggi M. Metabolic syndrome and benign prostatic enlargement: a systematic review and meta-analysis. BJU Int 2015;115:2431.

18. Averbeck MA, Madersbacher H. Constipation and LUTS - how do they affect each other? Int Braz J Urol 2011;37:16-28.

19. Chase JW, Homsy Y, Siggaard C, Sit F, Bower WF. Functional constipation in children. J Urol 2004;171:2641-2643.

20. Saga S, Vinsnes AG, Mørkved S, Norton C, Seim A. What characteristics predispose to continence in nursing home residents?: a population-based cross-sectional study. Neurourol Urodyn 2015;34:362-367. 